\title{
First report of grapevine rupestris vein feathering virus in grapevine in Iran
}

\author{
Maryam Khalili ${ }^{1}$ Shaheen Nourinejhad Zarghani ${ }^{2,3} \cdot$ Sebastien Massart ${ }^{4} \cdot$ Akbar Dizadji $^{1} \cdot$ Antonio Olmos $^{5}$. \\ Thierry Wetzel $^{2} \cdot$ Ana Belén Ruiz-García ${ }^{5}$ (I)
}

Received: 17 May 2020 / Accepted: 23 June 2020 / Published online: 13 July 2020

(C) Società Italiana di Patologia Vegetale (S.I.Pa.V.) 2020

Keywords Grapevine rupestris vein feathering virus $\cdot$ HTS $\cdot$ grapevine $\cdot$ marafivirus

Grapevine rupestris vein feathering virus (GRVFV) is a putative member of the genus Marafivirus, family Tymoviridae, reported to infect grapevine for the first time in Greece. Since then, GRVFV has been found in the USA, Canada, Uruguay, Italy, Spain, the Czech Republic, China, Switzerland, New Zealand, Korea, Germany, Slovakia and Pakistan (Glasa et al. 2018; Mahmood et al. 2019). In July 2016, a grapevine sample from cultivar Salatine (R8) showing vein banding symptoms was collected in Takestan (Qazvin province, Iran) and analyzed by high throughput sequencing using RNAseq TrueSeq Illumina technology. Data analysis was performed by CLC Genomics Workbench 10.1.1 software. After quality control, $8,177,870$ reads were subjected to host genome subtraction and the 837,566 grapevine unrelated reads used to assemble de novo 5164 contigs. BLAST analysis revealed the presence of one contig of $375 \mathrm{nt}$ related to GRVFV. Contigs related to grapevine leafroll-associated virus 7 , Australian grapevine viroid, grapevine yellow speckle viroid

Maryam Khalili and Shaheen Nourinejhad Zarghani contributed equally to this work.

Ana Belén Ruiz-García

ana.belen.ruiz@uv.es

1 Department of Plant Protection, College of Agriculture and Natural Resources, University of Tehran, Karaj, Iran

2 DLR Rheinpfalz, Institute of Plant Protection, Breitenweg, 71 Neustadt an der Weinstrasse, Germany

3 Department of Plant Protection, College of Abouraihan, University of Tehran, Tehran, Iran

4 Plant Pathology Laboratory, TERRA, Gembloux Agro-Bio Tech, University of Liège, Gembloux, Belgium

5 Instituto Valenciano de Investigaciones Agrarias, 46113 Moncada, Valencia, Spain
1 and hop stunt viroid were also found. The 837,566 reads were mapped using as references full-length GRVFV sequences, allowing the recovery of $70.1 \%$ (4699 nt) of the GRVFV genome in 13 partial genomic sequences. Among them, a fragment of $861 \mathrm{nt}$ (MN228563) in the protease/ helicase region and a fragment of $576 \mathrm{nt}(\mathrm{MN} 228562)$ in the RNA-dependent RNA polymerase region showed $83.04 \%$ and $84.72 \%$ similarity with isolates ChTK0004 (MF000326) and Ch8021(MF000325) from New Zealand, respectively. To confirm the presence of GRVFV in R8 sample, a $445 \mathrm{bp}$ fragment was amplified by RT-PCR, using primers $5^{\prime}$ ACTCWCYATCCCCTTCCAGT-3' and 5'-GCTG ACCATGCCACGAATCA-3' (Reynard et al. 2017). Sanger sequencing of the PCR product (MN206077) confirmed the presence of GRVFV in R8 sample. In addition, a total of 23 out of 38 samples collected from different Iranian vineyards tested positive for GRVFV by RT-PCR. To our knowledge this is the first report of GRVFV in Iran.

\section{References}

Glasa M, Predajňa L, Wetzel T, Šoltys K, Sabanadzovic S (2018) First report of grapevine rupestris vein feathering virus in grapevine in Slovakia. Plant Dis 103:170. https://doi.org/10.1094/PDIS-06-181112-PDN

Mahmood M, Gentili A, Naz S, Faggioli F (2019) First report of grapevine rupestris vein feathering virus in Pakistan. J Plant Pathol. https://doi.org/10.1007/s42161-019-00319-1

Reynard JS, Brodard J, Dubuis N, Yobregat O, Kominek P, Schumpp O, Schaerer S (2017) First report of grapevine rupestris vein feathering virus in swiss grapevines. Plant Dis 101:1062. https://doi.org/10. 1094/PDIS-01-17-0140-PDN

Publisher's note Springer Nature remains neutral with regard to jurisdictional claims in published maps and institutional affiliations. 